\title{
The Seville Statement on Violence
}

Can war be abolished? Is it a custom or is it intrinsic to human nature? These questions are of great importance today, because there is no task more important on the historical agenda of our times than the abolition of this age-old custom that has become so destructive that it threatens the very life of the planet. As Sigmund Freud wrote to Albert Einstein in their famous correspondence of 1932 on this subject, "These two factors --man's cultural disposition and well-founded fear of the form that future wars will take -- may serve to put an end to war ... but by what ways or byways this will come about, we cannot guess."

Studies among various populations have found that about half of all young people belief that war is intrinsic to human nature (Granberg, 1975; Eckhardt, 1972; Wahlstrom, 1985; Adams and Bosch, 1987). And one study has shown that those who believe that war is part of human nature are less likely than others to take any action in favor of peace (Adams and Bosch, 1987).

In 1986, twenty leading scientists from around the world examined the relevant scientific data (Ramirez, Hinde and Groebel, 1987) and issued a Statement that the evidence does not show that war is part of human nature. Paraphrasing the UNESCO Constitution and the words of the anthropologist Margaret Mead, they concluded that "Just as 'wars begin in the minds of men', peace also begins in our minds. The same species who invented war is capable of inventing peace. The responsibility lies with each of us."

The text of the Seville Statement, reprinted below, was widely distributed around the world by many social activists and scientists, as documented in the Seville Statement Newletter (1986-2003), which is available on the Internet at http://www.culture-ofpeace.info/ssov_newsletter.html . The 2002 newsletter (updated recently) lists 148 publications of the Statement in 17 languages, and this is doubtlessly an underestimate.

The Seville Statement was adopted as policy by the United Nations Educational, Scientific and Cultural Organization, as well as many leading scientific organizations (Adams, 1989, 1991). These include the three relevant organizations of social scientists in the United States, the American Psychological, Anthropological and Sociological Associations.

Despite the widespread distribution and publication of the Seville Statement in over 30 languages, it is still common to find articles in popular media, including those devoted to science, claiming that warfare is biologically determined or instinctive. Hence, it is important to continue the task of educating the public, including scientists, about these issues.

SEVILLE STATEMENT ON VIOLENCE, SPAIN, 1986 (SUBSEQUENTLY ADOPTED BY UNESCO AT THE TWENTY-FIFTH SESSION OF THE GENERAL CONFERENCE ON 16 NOVEMBER 1989) 
Believing that it is our responsibility to address from our particular disciplines the most dangerous and destructive activities of our species, violence and war; recognizing that science is a human cultural product which cannot be definitive or all-encompassing; and gratefully acknowledging the support of the authorities of Seville and representatives of the Spanish UNESCO; we, the undersigned scholars from around the world and from relevant sciences, have met and arrived at the following Statement on Violence. In it, we challenge a number of alleged biological findings that have been used, even by some in our disciplines, to justify violence and war. Because the alleged findings have contributed to an atmosphere of pessimism in our time, we submit that the open, considered rejection of these mis-statements can contribute significantly to the International Year of Peace.

Misuse of scientific theories and data to justify violence and war is not new but has been made since the advent of modern science. For example, the theory of evolution has been used to justify not only war, but also genocide, colonialism, and suppression of the weak.

We state our position in the form of five propositions. We are aware that there are many other issues about violence and war that could be fruitfully addressed from the standpoint of our disciplines, but we restrict ourselves here to what we consider a most important first step.

IT IS SCIENTIFICALLY INCORRECT to say that we have inherited a tendency to make war from our animal ancestors. Although fighting occurs widely throughout animal species, only a few cases of destructive intra-species fighting between organized groups have ever been reported among naturally living species, and none of these involve the use of tools designed to be weapons. Normal predatory feeding upon other species cannot be equated with intra-species violence. Warfare is a peculiarly human phenomenon and does not occur in other animals.

The fact that warfare has changed so radically over time indicates that it is a product of culture. Its biological connection is primarily through language which makes possible the co-ordination of groups, the transmission of technology, and the use of tools. War is biologically possible, but it is not inevitable, as evidenced by its variation in occurrence and nature over time and space. There are cultures which have not engaged in war for centuries, and there are cultures which have engaged in war frequently at some times and not at others.

IT IS SCIENTIFICALLY INCORRECT to say that war or any other violent behaviour is genetically programmed into our human nature. While genes are involved at all levels of nervous system function, they provide a developmental potential that can be actualized only in conjunction with the ecological and social environment. While individuals vary in their predispositions to be affected by their experience, it is the interaction between their genetic endowment and conditions of nurturance that determines their personalities. Except for rare pathologies, the genes do not produce individuals necessarily predisposed to violence. Neither do they determine the opposite. While genes are co-involved in establishing our behavioural capacities, they do not by themselves specify the outcome. 
IT IS SCIENTIFICALLY INCORRECT to say that in the course of human evolution there has been a selection for aggressive behaviour more than for other kinds of behaviour. In all well-studied species, status within the group is achieved by the ability to co-operate and to fulfill social functions relevant to the structure of that group. 'Dominance' involves social bindings and affiliations; it is not simply a matter of the possession and use of superior physical power, although it does involve aggressive behaviours. Where genetic selection for aggressive behaviour has been artificially instituted in animals, it has rapidly succeeded in producing hyper-aggressive individuals; this indicates that aggression was not maximally selected under natural conditions. When such experimentally-created hyper-aggressive animals are present in a social group, they either disrupt its social structure or are driven out. Violence is neither in our evolutionary legacy nor in our genes.

IT IS SCIENTIFICALLY INCORRECT to say that humans have a 'violent brain'. While we do have the neural apparatus to act violently, it is not automatically activated by internal or external stimuli. Like higher primates and unlike other animals, our higher neural processes filter such stimuli before they can be acted upon. How we act is shaped by how we have been conditioned and socialized. There is nothing in our neurophysiology that compels us to react violently.

IT IS SCIENTIFICALLY INCORRECT to say that war is caused by 'instinct' or any single motivation. The emergence of modern warfare has been a journey from the primacy of emotional and motivational factors, sometimes called 'instincts', to the primacy of cognitive factors. Modern war involves institutional use of personal characteristics such as obedience, suggestibility, and idealism, social skills such as language, and rational considerations such as cost-calculation, planning, and information processing. The technology of modern war has exaggerated traits associated with violence both in the training of actual combatants and in the preparation of support for war in the general population. As a result of this exaggeration, such traits are often mistaken to be the causes rather than the consequences of the process.

We conclude that biology does not condemn humanity to war, and that humanity can be freed from the bondage of biological pessimism and empowered with confidence to undertake the transformative tasks needed in this International Year of Peace and in the years to come. Although these tasks are mainly institutional and collective, they also rest upon the consciousness of individual participants for whom pessimism and optimism are crucial factors. Just as 'wars begin in the minds of men', peace also begins in our minds. The same species who invented war is capable of inventing peace. The responsibility lies with each of us.

Seville, 16 May 1986

David Adams, Psychology, Wesleyan University, Middletown, CT., U.S.A.

S.A. Barnett, Ethology, The Australian National University, Canberra, Australia 
N.P. Bechtereva, Neurophysiology, Institute for Experimental Medicine of Academy of Medical Sciences of the U.S.S.R., Leningrad, U.S.S.R.

Bonnie Frank Carter, Psychology, Albert Einstein Medical Center, Philadelphia (PA), U.S.A.

José M. Rodriguez Delgado, Neurophysiology, Centro de Estudios Neurobiologicos, Madrid, Spain

José Luis Diaz, Ethology, Instituto Mexicano de Psiquiatria, Mexico D.F., Mexico

Andrzej Eliasz, Individual Differences Psychology, Polish Academy of Sciences, Warsaw, Poland

Santiago Genovés, Biological Anthropology, Instituto de Estudios Antropologicos, Mexico D.F., Mexico

Benson E. Ginsburg, Behavior Genetics, University of Connecticut, Storrs, CT., U.S.A.

Jo Groebel, Social Psychology, Erziehungswissenschaftliche Hochschule, Landau, Federal Republic of Germany

Samir-Kumar Ghosh, Sociology, Indian Institute of Human Sciences, Calcutta, India

Robert Hinde, Animal Behaviour, Cambridge University, Cambridge, U.K.

Richard E. Leakey, Physical Anthropology, National Museums of Kenya, Nairobi, Kenya

Taha H. Malasi, Psychiatry, Kuwait University, Kuwait

J. Martin Ramirez, Psychobiology, Universidad de Sevilla, Spain

Federico Mayor Zaragoza, Biochemistry, Universidad Autonoma, Madrid, Spain

Diana L. Mendoza, Ethology, Universidad de Sevilla, Spain

Ashis Nandy, Political Psychology, Centre for the Study of Developing Societies, Delhi, India

John Paul Scott, Animal Behavior, Bowling Green State University, Bowling Green, OH., U.S.A.

Riitta Wahlstrom, Psychology, University of Jyväskylä, Finland 


\section{References}

Adams, D. (1989). The Seville Statement on Violence: A Progress Report. Journal of Peace Research, (No. 26): 113-121. Available on Internet at http://www.culture-ofpeace.info/ssov/title-page.html .

Adams, D. (1991). The Seville Statement on Violence: Preparing the Ground for the Construction of Peace, Paris, France: UNESCO. Available on Internet at http://www.culture-of-peace.info/brochure/titlepage.html

Adams, D. and Bosch, S. (1987). The Myth that War is Intrinsic to Human Nature Discourages Action for Peace by Young People. In Essays on Violence. Sevilla: Universidad de Sevilla, Available on Internet at http://www.culture-ofpeace.info/myth/title-page.html

Eckhardt, W. (1972). Crosscultural Theories of War and Aggression. International Journal of Group Tensions (No. 2): 36-51.

Granberg, D. (1975). War Expectancy and the Evaluation of a Specific War. Conflict Resolution (No. 3): 546-549.

Ramirez, J. M., Hinde, R. A., and Groebel, J. (1987). Essays on Violence. Sevilla: Universidad de Sevilla.

The Seville Statement on Violence. (1990). American Psychologist (No. 45): 1167-1168.

Wahlstrom, R. (1985). On the Psychological Premises for Peace Education. Third European Conference of International Society for Research on Aggression. Parma, Italy. 